Diterima: 06/05/2021, Direview: 11/06/2021, Diterbitkan: 31/01/2022

\title{
SIFAT FISIKOKIMIA DAN HEDONIK COOKIES OATS DENGAN PENGGUNAAN TEPUNG KULIT BUAH NAGA MERAH (Hylocereus polyrhizus)
}

\section{Physicochemical Properties and Hedonic of Oats Cookies with The Utilization of Red Dragon Fruit Peel Flour (Hylocereus Polyrhizus)}

\author{
Frederick Wijaya*, Antonius Hintono, Yoyok Budi Pramono \\ Program Studi Teknologi Pangan, FPP Universitas Diponegoro, Semarang \\ JI. Prof. Soedarto Tembalang Semarang Jawa Tengah 50275 \\ *Penulis Korespondensi, Email: frederickwijaya14@gmail.com
}

\begin{abstract}
ABSTRAK
Riset ini bertujuan untuk menelaah efek penggunaan tepung kulit buah naga merah (KBNM) tiap konsentrasi yang diberikan pada cookies oats terhadap sifat fisikokimia dan hedonik produk. Manfaat penelitian ini untuk mendapatkan cookies oats terbaik dengan memanfaatkan hasil samping limbah berupa KBNM menjadi produk berbasis pangan fungsional. Rancangan percobaan berupa rancangan acak lengkap (RAL). Perlakuan berdasarkan dari $\mathrm{T}_{0}, \mathrm{~T}_{1}, \mathrm{~T}_{2}$ dan $\mathrm{T}_{3}$ memiliki perbandingan antara tepung KBNM dan tepung terigu berturut-turut sebesar 0\%:100\%, 20\%:80\%, 40\%:60\% dan 60\%:40\% dengan 5 kali pengulangan. Parameter yang diujikan adalah aktivitas antioksidan, aktivitas air, tekstur, warna dan penilaian hedonik cookies. Hasil penelitian menunjukkan bahwa perlakuan penggunaan tepung KBNM 20\% memiliki aktivitas antioksidan $28.39 \%$, aktivitas air 0.325 , tekstur renyah, Warna paling merah dan penilaian hedonik paling disukai. Simpulan pada penelitian ini adalah bahwa perlakuan terbaik terdapat pada perlakuan $\mathrm{T}_{1}$ yang memiliki karakteristik tekstur serupa dengan cookies pada umumnya dengan aktivitas antioksidan yang lebih tinggi.
\end{abstract}

Kata kunci: Antioksidan, Cookies, Kulit buah naga, Oat

\begin{abstract}
This research was to know the effect of using red dragon fruit peel (RDFP) flour for each concentration used in oats cookies towards physicochemical and hedonic characteristics. The benefit of research is to earn the most optimum oats cookies by utilizing the waste by-product RDFP to be products as functional food. The trials design used completely randomized design (CRD). The treatments consisted of $T_{0}, T_{1}, T_{2}$ and $T_{3}$, each treatments had a ratio concentration of RDFP flour and wheat flour of $0 \%: 100 \%, 20 \%: 80 \%$, 40\%:60\%, and 60\%:40\% respecively with 5 replications. The results indicated that the treament of using $20 \%$ RDFP flour had antioxidant activity $28.39 \%$, water activity 0.325 , crispy texture, the reddest colour and the most liked. The Conclusion were the best treatment utilzation of RDFP flour in oats cookies on treatment T1 which has characteristic texture like a common cookies with more antioxidant activity.
\end{abstract}

Keywords: Antioxidan, Cookies, Dragon fruit peel, Oats

\section{PENDAHULUAN}

Buah naga merah mengandung zat yang baik untuk meningkatkan stamina dan mempercepat sistem metabolisme, karena buah naga merah mempunyai nilai ekonomi yang tinggi sehingga dapat menurunkan gula darah dan kolesterol. Buah naga merah berpotensi 
dijadikan salah satu pangan berbasis fungsional dengan adanya zat antosianin, serat yang tinggi serta betasianin. Konsumsi buah naga merah pada umumnya hanya diambil bagian daging buah sebagai jus, es krim, sirup dan lainnya. Limbah kulit buah naga yang menguntungkan dari segi kesehatan ini belum banyak dimanfaatkan. (Manihuruk et al., 2017). Kandungan gizi berupa total fenol dan flavonoid yang terkandung dalam kulit lebih kaya dibandingkan dengan daging buah, terutama dari komposisi serat, antioksidan dan zat mikro lainnya. Total fenol pada kulit buah naga merah yang terkandung didalamnya sejumlah $1049.18 \mathrm{mgGAE} / 100 \mathrm{gr}$ dan total flavonoid sejumlah $1310.10 \mathrm{mgGAE} / 100 \mathrm{gr}$, lebih besar $3 \mathrm{kali}$ lipat dibandingkan isi buah (Nurliyana et al., 2010). Pengolahan kulit buah naga merah dapat berupa ekstrak, bubur/pasta dan tepung yang berpotensi sebagai pangan fungsional jika ditambahkan kedalam suatu produk pangan.

Cookies merupakan salah satu snack yang sering dijumpai dan mudah dikonsumsi oleh masyarakat. Cookies yang banyak dijual di pasaran umumnya cenderung mempunyai kadar lemak yang tinggi dan berserat rendah karena komponen bahan - bahan penyusunnya seperti tepung, margarin, kuning telur dan susu skim (Iswara et al., 2019). Cookies dengan penambahan oats mempunyai dampak yang baik bagi kesehatan salah satunya menurunkan kadar kolesterol. Cookies juga memiliki kemudahan dalam melakukan substitusi tepung terigu yang dapat meningkatkan gizi tertentu karena sifat cookies yang membutuhkan gluten rendah. Selain gizi, penggunaan kulit buah naga merah dapat memperbaiki sifat fisik, terutama pada warna dengan adanya senyawa antosianin sebagai pewarna merah alami. Maka dari itu, pengurangan tepung terigu dengan penggunaan tepung lainnya menjadi solusi dalam pemecahan masalah tersebut. Penggunaan kulit buah naga merah sebagai tepung terhadap cookies oats perlu diketahui konsentrasi terbaik yang ditambahkan ke dalamnya. Manfaat yang didapatkan dapat terciptanya cookies oats dengan pemanfaatan hasil samping limbah berupa kulit buah naga merah yang berpotensi sebagai pangan fungsional yang terutama kaya antioksidan, serat, dan sesuai dengan preferensi konsumen.

\section{BAHAN DAN METODE}

Penelitian dilakukan pada Oktober 2020 - Desember 2020 di Laboratorium Kimia dan Gizi Pangan, Laboratorium Rekayasa Pangan dan Hasil Peternakan Fakultas Peternakan dan Pertanian, Universitas Diponegoro, Semarang serta Laboratorium Terpadu Universitas Diponegoro, Semarang.

\section{Bahan}

Bahan tepung utama penelitian ini adalah kulit buah naga merah (Hylocereus polyrhizus) segar pada hari yang sama diperoleh dari Superindo Majapahit, Semarang. Pembuatan cookies oats yang digunakan terdiri dari margarin, gula halus, tepung terigu protein rendah, telur, baking powder, garam, perisa red velvet dan perisa vanilla. Bahan analisis yang digunakan dalam penelitian terdiri dari etanol 95\%, reagen DPPH (1,1 diphenil2-picryllhydrazil).

Alat

Alat yang digunakan dalam penelitian ini yakni pisau, talenan, food processor (PHILIPS), cabinet dryer (MAKSINDO), aluminium foil, timbangan analitik, mixer, baskom, spatula, oven, LabSwift Novasina Portable Water Activity (NOVASINA), Chromatography GC (SHIMADZU), Texture Analyzer (BROOKFIELD), Colorimetri (CIE-HUNTER LAB).

\section{Desain Penelitian}

Penelitian memakai rancangan acak lengkap (RAL) memiliki 4 perlakuan dengan konsentrasi tepung kulit buah naga merah yakni $0 \%\left(T_{0}\right), 20 \%\left(T_{1}\right), 40 \%\left(T_{2}\right)$ dan $60 \%\left(T_{3}\right)$. Dilakukan pengulangan sebanyak 5 kali sehingga terdapat 20 unit sampel. 


\section{Tahapan Penelitian}

Tahapan Pembuatan Tepung Kulit Buah Naga Merah

Pembuatan tepung mengacu pada Rochmawati, (2019). Kulit buah dicuci dengan air matang dan di-blanching dengan suhu 95 - 100oC selama 2 - 3 menit. Kulit buah dipotong untuk mengurangi volume dan diletakan ke dalam loyang yang telah ditutupi alumunium foil. Kulit buah yang sudah disusun dimasukkan ke dalam cabinet dryer dengan suhu 60 oC selama waktu 18 jam hingga kulit buah naga merah kering. Kulit buah kering dimasukkan kedalam food processor dan dihaluskan menjadi tepung yang disaring dengan ukuran 30 40 mesh.

\section{Tahapan Pembuatan Cookies Oats}

Pembuatan cookies oats mengacu pada Wulandari et al., (2016) yang dimodifikasi dilakukan dengan tiga tahapan yaitu pembuatan adonan (pencampuran), pencetakan adonan dan pemanggangan. Bahan-bahan disiapkan dan ditimbang sesuai dengan Tabel 1. Margarin, gula halus, telur, perisa vanilla dan red velvet di mixing cepat selama 3 menit. Tepung terigu protein rendah, tepung kulit buah naga merah, baking powder dan garam dimasukkan ke dalam adonan lalu di mixing lambat hingga kalis selama 5 menit. Kemudian ditambahkan cooking oats dan diaduk dengan spatula hingga rata. Adonan dicetak sama rata sebesar kurang lebih $5-7$ gram lalu dilakukan pengovenan dengan suhu $150{ }^{\circ} \mathrm{C}$ selama 20 menit. Cookies yang sudah matang dilakukan pendinginan selama 15 menit pada suhu ruang.

\section{Metode}

Parameter yang diamati meliputi parameter kimia yang terdiri dari aktivitas antioksidan dengan spektrofotometri menggunakan reagen DPPH (Vistia and Putri, 2014), aktivitas air menggunakan $a_{w}$ meter (Ulfah et al., 2018). Parameter fisik terdiri dari analisis tekstur dengan alat texture analyzer (Iswara et al., 2019) dan warna dengan colorimetri LAB (Mamuaja et al., 2017) serta parameter sensori berupa uji hedonik 25 panelis semi terlatih.

\section{Aktivitas Antioksidan}

5 gram cookies oats ditimbang. Cookies oats dilarutkan dengan etanol 95\% dengan cara dicampurkan sekitar $200 \mathrm{ml}$. Pemisahan ekstrak dengan sentrifugasi kecepatan 4000 rpm selama 10 menit. Hasil sentrifugasi $4 \mathrm{ml}$ diberi $1 \mathrm{ml}$ larutan 1,1 diphenil-2-picryllhydrazil (DPPH) $0.20 \mathrm{M}$. Diukur absorbansi secara spektrofotometri. Perhitungan aktivitas antioksidan didapatkan dari rumus:

Inhibisi $(\%)=\left(\frac{\text { Abs Awal-Abs Akhir }}{\text { Abs Awal }}\right) \times 100 \%$

Keterangan:

Abs Awal = Nilai absorbansi sebelum direaksikan DPPH

Abs Akhir = Nilai absorbansi setelah direaksikan DPPH

\section{Aktivitas Air}

sampel cookies oats dimaserasi hingga halus kemudian ditaruh ke dalam alat. Layar menampilkan progres pengukuran ketika layar menunjukkan indikasi analyze. Nilai akan mengindikasikan konstan ketika alat mengeluarkan suara peringatan pengukuruan $\mathrm{a}_{\mathrm{w}}$ selesai.

Tekstur

Uji tekstur pada cookies oats meliputi uji nilai hardness, springiness, adhesiveness dan cohesiveness. Sampel diletakan dalam meja objek dan dilakukan tombol mulai. Komputer memproses data hasil pengukuran dalam bentuk grafik.

Warna

Chromameter di lakukan setting callibration dengan standar warna putih yang terdapat pada chromameter. Skala nilai $L$ dimulai dari paling gelap ke paling cerah dengan skala skor 0-100, nilai a merupakan merah (+), hijau (-) dan nilai b merupakan $\mathrm{n}$ kuning (+), 
biru (-). Sampel diambil sebanyak 1 butir dan dimasukkan ke dalam garis kotak kertas putih yang kemudian ditekan tombol untuk p-review video. Hasil uji akan keluar setelah dalam display dan dibandingkan antara warna standar dengan warna sampel yang tertera.

Hedonik

Sifat hedonik dilakukan dengan menggunakan 25 panelis semi terlatih. Setiap panelis diberi masing - masing 4 buah cookies perlakuan T0, T1, T2 dan T3 diletakkan kedalam wadah yang telah diberi kode 3 angka secara acak. Panelis menilai sesuai dengan tingkat kesukaan masing - masing kemudian skor dituliskan pada lembar form yang telah disediakan. Skor kesukaan terdiri dari skor 1 - 4 dengan kriteria sangat suka (4), suka (3), sedikit suka (2) dan tidak suka (1). Parameter yang dinilai yakni mengenai warna, aroma, tekstur, rasa dan overall.

\section{Prosedur Analisis}

Data uji aktivitas air, tekstur dan warna dianalisis menggunakan ANOVA dan diteruskan Duncan's Mutiple Range Test guna menentukan pengaruh tidaknya setiap perlakuan. Data hedonik menggunakan Kruskal-Wallis dilanjutkan dengan Mann-Whitney guna menentukan perbedaan dari setiap perlakuan. Data diolah melalui aplikasi IBM SPSS 26.0. Data uji aktivitas antioksidan di analisis secara deskriptif.

\section{HASIL DAN PEMBAHASAN}

\section{Aktivitas Antioksidan}

Data aktivitas antioksidan penggunaan tepung kulit buah naga merah terhadap cookies secara deskriptif, tertera pada Tabel 1.

Tabel 1. Aktivitas Antioksidan Cookies Oats Tepung Kulit Buah Naga Merah

\begin{tabular}{cc}
\hline Konsentrasi Tepung KBNM & Nilai Aktivitas Antioksidan (\% Inhibisi) \\
\hline 0 & 22.82 \\
20 & 28.39 \\
40 & 35.25 \\
60 & 39.15 \\
\hline
\end{tabular}

Berdasarkan Tabel 1. semakin tinggi konsentrasi penggunaan tepung akan menambah aktivitas antioksidan yang terkandung dalam cookies oats. Kenaikan yang terjadi seiring dengan bertambahnya konsentrasi tepung aktivitas antioksidan dalam jumlah yang banyak antara lain antosianin dan beberapa senyawa antioksidan lainnya didalam kulit buah naga. Noor et al., (2016) berpendapat bahwa kulit buah naga memiliki kandungan antioksidan berupa polifenol, antosianin, tanin, vitamin C dan saponin berdasarkan pengujian FTIR. Antosianin merupakan senyawa flavonoid paling melimpah pada kulit buah naga merah yang dapat mengikat radikal bebas karena memiliki gugus hidroksil untuk melepas proton dalam bentuk ion hidrogen. Menurut Budilaksono et al., (2014) antosianin memiliki daya menangkal radikal bebas yang kuat dikarenakan ion hidrogen yang cukup banyak sehingga atom hidrogren radikal bebas saling berikatan dan radikal bebas tereduksi yang dibuktikan dengan pengujian DPPH.

\section{Aktivitas Air}

Data aktivitas air penggunaan tepung kulit buah naga merah terhadap cookies, tertera dari Tabel 2. Berdasarkan Tabel 2. dapat diketahui bahwa konsentrasi penggunaan tepung yang berbeda mempunyai pengaruh nyata $(p<0.05)$ terhadap aktivitas air. Aktivitas air yang dimiliki oleh tiap percobaan memiliki nilai rerata antara $0.304-0.374$. Angka tersebut bersifat normal untuk produk jenis kue kering seperti cookies. Menurut Sarifudin et al., (2015) aktivitas air pada produk kering seperti biskuit dan cookies dengan nilai aktivitas air dibawah 0.5 memiliki umur simpan yang panjang. penggunaan tepung kulit buah naga juga memiliki 
kemampuan untuk mengikat air yakni dipengaruhi oleh kandungan pektin yang terkandung dalam tepung sehingga kadar air bebas semakin berkurang. Sejalan dengan Winarti et al., (2020) yang berpendapat bahwa pektin dalam pangan memiliki fungsi untuk mengikat air, pengental dan membentuk struktur suatu pangan. Daya ikat air sendiri juga dipengaruhi oleh tingginya kadar serat yang dimiliki oleh kulit buah naga merah. Serat pangan yang terkandung di kulit buah naga merah per $100 \mathrm{~g}$ buah sebesar 2.71\% (Nurliyana et al., (2010). Serat pangan larut air memiliki kemampuan daya untuk mengikat air. Hal ini didukung oleh Sánchez-Muniz, (2012) yang menyatakan bahwa air akan diikat oleh serat secara kimia pada gugusan hidrofilik sehingga air bebas yang dapat diuapkan semakin berkurang dan dapat menurunkan kadar air. Penurunan kadar air bebas dalam cookies juga dipengaruhi oleh proses pemanggangan. Kenaikan aktivitas air dipengaruhi oleh daya ikat air yang terkandung dalam adonan.

Tabel 2. Aktivitas Air Cookies Oats Tepung Kulit Buah Naga Merah

\begin{tabular}{cc}
\hline Konsentrasi Tepung KBNM & Nilai Aktivitas Air $\left(a_{w}\right)$ \\
\hline $0 \%$ & $0.304 \pm 0.0201^{\mathrm{a}}$ \\
$20 \%$ & $0.325 \pm 0.0502^{\mathrm{a}}$ \\
$40 \%$ & $0.341 \pm 0.0184^{\mathrm{ab}}$ \\
$60 \%$ & $0.374 \pm 0.0185^{\mathrm{b}}$
\end{tabular}

a-b Nilai dikolom yang sama menunjukkan pengaruh nyata $(p<0.05)$.

\section{Tekstur}

Data tekstur terhadap cookies oats meliputi hardness, cohessiveness, springiness dan adhesiveness, tertera pada Tabel 3.

Tabel 3. Tekstur Cookies Oats Tepung Kulit Buah Naga Merah

\begin{tabular}{ccccc}
\hline Konsentrasi & \multicolumn{4}{c}{ Parameter } \\
\cline { 2 - 4 } $\begin{array}{c}\text { Tepung } \\
\text { KBNM }\end{array}$ & Hardness & Cohessiveness & Springiness & Adhesiveness \\
\hline $0 \%$ & $1971.00 \pm 575.50^{\mathrm{a}}$ & $0.04 \pm 0,02^{\mathrm{a}}$ & $4.48 \pm 0.41^{\mathrm{a}}$ & $0.35 \pm 0.34$ \\
$20 \%$ & $2045.90 \pm 1312.50^{\mathrm{a}}$ & $0.07 \pm 0,02^{\mathrm{ab}}$ & $4.04 \pm 0.55^{\mathrm{a}}$ & $0.45 \pm 0.35$ \\
$40 \%$ & $3700.80 \pm 879.17^{\mathrm{b}}$ & $0.08 \pm 0,02^{\mathrm{b}}$ & $3.70 \pm 0.14^{\mathrm{ab}}$ & $0.56 \pm 0.21$ \\
$60 \%$ & $4527.70 \pm 1267.86^{\mathrm{b}}$ & $0.13 \pm 0,04^{\mathrm{c}}$ & $3.52 \pm 0.65^{\mathrm{b}}$ & $0.57 \pm 0.12$ \\
\hline
\end{tabular}

a-b Nilai di kolom yang sama menunjukkan pengaruh nyata $(p<0.05)$.

Berdasarkan Tabel 3. dapat dilihat bahwa penggunaan tepung berpengaruh nyata $(p<0.05)$ terhadap parameter tekstur yang meliputi hardness, cohesiveness dan springiness tetapi tidak berpengaruh nyata terhadap adhesiveness. Semakin banyak penggunaan konsentrasi tepung akan menyebabkan cookies yang dihasilkan menjadi lebih keras. Kekerasan disebabkan karena adanya serat yang terkandung dalam tepung kulit buah naga merah. Kandungan protein tepung terigu dibandingkan tepung kulit buah naga yang lebih besar menyebabkan tekstur menjadi lebih renyah dengan tingkat kekerasan yang wajar. Hal ini didukung oleh Zhang et al., (2020) yang berpendapat jika protein pada tepung terigu dapat memperkuat ikatan antara amilopektin yang terjadinya degradasi membentuk pengembangan produk yang mengakibatkan produk menjadi renyah. Kandungan serat kasar berupa selulosa dan lignin yang terkandung dalam kulit buah naga merah diduga juga bisa mengganggu proses gelatinisasi pada cookies sehingga tekstur produk menjadi lebih keras. Kandungan pektin yang terkandung dapat menyebabkan menaikan nilai cohesiveness akibat penyerapan air.

Springiness akan mengalami pengurangan seiring dengan adanya proses pemanasan suhu tinggi. Sejalan dengan Venturini et al. (2019) yang berpendapat bahwa pemanasan temperatur tinggi dengan intensitas waktu yang cukup lama menyebabkan produk pangan kehilangan kadar air sehingga mempengaruhi tekstur springiness. Senyawa polifenol dan serat kasar yang dapat mengurangi nilai springiness dalam cookies. Sejalan dengan Girard 
and Awika, (2020) yang menyatakan bahwa senyawa fenol, selulosa dan lignin dapat menyebabkan berkurangnya nilai viskoelastisitasnya dengan cara mengurangi kekuatan ikatan gluten selama proses gelatinisasi. Seiring dengan besarnya jumlah konsentrasi tepung kulit buah naga merah ditunjukkan bahwa terjadinya juga kenaikan nilai adhesiveness pada cookies oats. Gugus hidroksil dalam molekul polifenol yang terkandung sehingga penyerapan air yang maksimal membentuk kepaduan adonan cookies. Sejalan dengan Sari et al., (2020) yang mengatakan gugus hidroksil pada polifenol dapat menyerap air. Penyerapan air yang maksimal akan membentuk kepaduan pada adonan cookies.

\section{Warna}

Data warna cookies oats meliputi rerata warna $L^{*}, a^{*}$ dan $b^{*}$. Hasil visual dan pengujian tertera pada Gambar 1. dan Tabel 4.

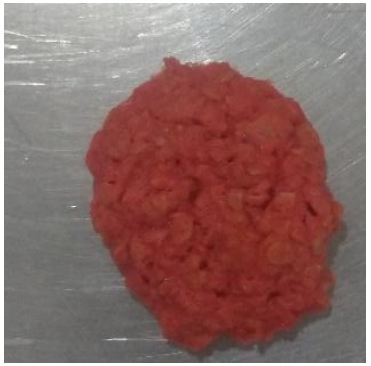

a

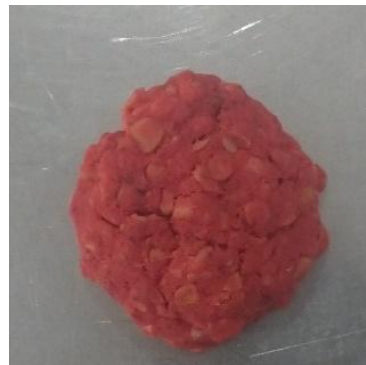

b

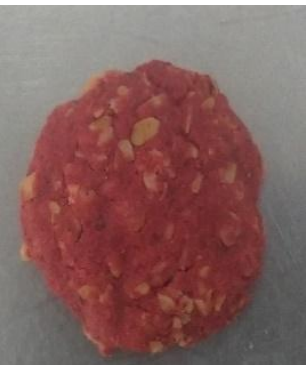

C

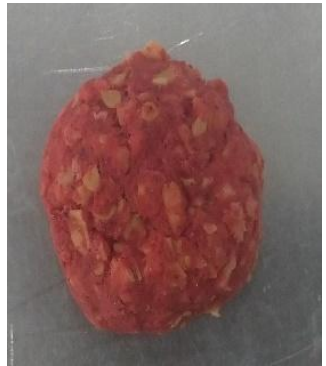

d

Gambar 1. Penampakan Warna Cookies Oats Konsentrasi tepung kulit buah naga merah a-d secara berurutan $0 \%, 20 \%, 40 \%$ dan $60 \%$

Tabel 4. Warna Cookies Oats Tepung Kulit Buah Naga Merah

\begin{tabular}{|c|c|c|c|}
\hline Konsentrasi Tepung KBNM & \multicolumn{3}{|c|}{ Rerata Warna } \\
\cline { 2 - 4 } & $\mathbf{L}^{*}$ & $\mathbf{a}^{\mathbf{*}}$ & $\mathbf{b}^{\boldsymbol{*}}$ \\
\hline $0 \%$ & $46.05 \pm 1.85^{\mathrm{a}}$ & $39.21 \pm 2.43^{\mathrm{a}}$ & $19.47 \pm 1.11^{\mathrm{a}}$ \\
\hline $20 \%$ & $40.21 \pm 1.25^{\mathrm{b}}$ & $45.03 \pm 2.47^{\mathrm{b}}$ & $16.40 \pm 1.47^{\mathrm{b}}$ \\
\hline $40 \%$ & $37.17 \pm 1.24^{\mathrm{c}}$ & $38.25 \pm 1.48^{\mathrm{a}}$ & $14.87 \pm 1.11^{\mathrm{b}}$ \\
\hline $60 \%$ & $34.75 \pm 1.09^{\mathrm{d}}$ & $39.82 \pm 1.69^{\mathrm{a}}$ & $12.67 \pm 0.86^{\mathrm{c}}$ \\
\hline
\end{tabular}

${ }^{a-c}$ Nilai dikolom yang sama menunjukkan pengaruh nyata $(p<0.05)$.

Hasil pengujian warna Tabel 4, mengindikasikan bahwa konsentrasi penggunaan tepung yang berbeda mempunyai pengaruh nyata $(p<0.05)$. Semakin besar konsentrasi penggunaan tepung pada cookies maka akan menurunkan tingkat kecerahan dan warna kekuningan pada cookies. Penurunan kecerahan diduga karena kadar abu yang tinggi dalam kulit buah naga dengan rerata $0.8 \%-1.3 \%$ yang didapatkan dari total perhitungan proksimat akan menurunkan tingkat kecerahan. Sejalan dengan Rahmawati dan Nisa, (2015) yang berpendapat bahwa kadar abu menunjukkan tinggi rendahnya kandungan mineral dalam cookies yang semakin tinggi kadar abu yang terkandung akan menyebabkan cookies semakin gelap. Warna merah dihasilkan dari penggunaan konsentrasi kulit buah naga merah dengan adanya antosianin. Didukung Jalgaonkar et al., (2020) berpendapat yakni zat antosianin merupakan zat warna yang berdominan warna merah. Namun, pada perlakuan $T_{2}$ dan $T_{3}$ mengalami penurun warna merah yang seharusnya terjadi peningkatan warna merah akibat penggunaan konsentrasi tepung yang lebih tinggi. Intensitas warna dipengaruhi oleh suhu dan kadar pH pada saat pemanggangan. Sependapat dengan Alvionita et al., (2016) jika pemanggangan dengan suhu panas dan $\mathrm{pH}$ yang cenderung lebih tinggi akan menyebabkan kestabilan antosianin dalam mempertahankan warna menjadi berkurang. Warna kuning berkurang karena penambahan tepung dapat menutup warna hasil dari reaksi maillard. 
Didukung oleh Dewi et al., (2015) yang mengungkapkan bahwa reaksi maillard terjadi edoni adanya proses pemanasan terhadap bahan baku yang mengandung gula.

\section{Hedonik}

Data hedonik yang meliputi rerata warna $L^{*}, a^{*}$ dan $b^{*}$ pada cookies oats. Hasil visual dan pengujian tertera seperti pada Gambar 1. Dan Tabel 4.

Tabel 5. Nilai Hedonik Cookies Oats Tepung Kulit Buah Naga Merah

\begin{tabular}{lllll}
\hline Parameter & \multicolumn{3}{l}{ Perlakuan } & \multicolumn{3}{l}{} \\
\cline { 2 - 5 } & $\mathbf{0 \%}$ & $\mathbf{2 0} \%$ & $\mathbf{4 0 \%}$ & $\mathbf{6 0 \%}$ \\
\hline Warna & $2.24 \pm 0.97 \mathrm{a}$ & $3.52 \pm 0.59 \mathrm{~b}$ & $2.72 \pm 0.98 \mathrm{a}$ & $2.48 \pm 1.08 \mathrm{a}$ \\
Aroma & $3.08 \pm 0.86$ & $3.20 \pm 0.58$ & $3.08 \pm 0.81$ & $2.75 \pm 0.88$ \\
Tekstur & $3.48 \pm 0.65 \mathrm{a}$ & $3.28 \pm 0.46 \mathrm{a}$ & $2.44 \pm 0.82 \mathrm{~b}$ & $2.12 \pm 0.83 \mathrm{~b}$ \\
Rasa & $3.40 \pm 0.76 \mathrm{a}$ & $3.40 \pm 0.58 \mathrm{a}$ & $2.76 \pm 0.78 \mathrm{~b}$ & $2.20 \pm 0.82 \mathrm{c}$ \\
Overall & $3.36 \pm 0.76 \mathrm{a}$ & $3.60 \pm 0.50 \mathrm{a}$ & $2.80 \pm 0.76 \mathrm{~b}$ & $2.28 \pm 0.68 \mathrm{c}$ \\
\hline
\end{tabular}

a-c Nilai dikolom yang sama menunjukkan pengaruh nyata $(p<0.05)$.

Hasil pengujian hedonik Tabel 5. terhadap aroma tidak mempunyai pengaruh nyata $(p<0.05)$. Diduga penyusun formulasi cookies oats memiliki aroma citarasa yang kuat sehingga menghalangi aroma yang ditimbulkan dari kulit buah naga merah. Sependapat Subandoro et al., (2013) bahwa bahan yang terkandung seperti margarin dan gula menimbulkan aroma yang khas cookies seperti karamelisasi gula dan pemanasan margarin dalam adonan sehingga aroma cookies cenderung memiliki aroma yang sama. Pada atribut warna, tekstur, rasa dan overall berpengaruh nyata $(\mathrm{p}<0.05)$. Warna pada cookies oats penggunaan $20 \%$ tepung kulit buah aga merah lebih disukai karena memiliki tingkat kecerahan yang baik dengan warna merah yang paling menonjol hasil dari senyawa antosianin. Kesukaan panelis terhadap warna cookies dibandingkan dengan perlakuan kontrol disebabkan preferensi konsumen yang memiliki indra penglihatan yang cenderung tertarik terhadap cookies yang berwarna lebih merah pekat. Menurut Ingrath et al., (2015) penambahan kulit buah naga merah sebagai pewarna makanan, terutama pastry akan menambah daya tarik konsumen untuk mengkonsumsinya. Warna kuning semakin berkurang diindikasikan meningkatkan daya tarik konsumen karena pengurangan efek warna akibat reaksi maillard.

Perlakuan penggunaan tepung kulit buah naga merah dapat mengurangi kerenyahan yang dapat dilihat pada Tabel 6 . Tekstur cookies yang umumnya disukai oleh panelis adalah kerenyahan dan kekerasan yang seimbang, apabila dipatahkan akan memperlihatkan tekstur padat. Hal ini didukung oleh Cahyani, (2019) Cookies yang kerenyahan tidak terlalu tinggi atau rendah, mudah dipatahkan dan tekstur yang tidak kokoh atau padat merupakan tekstur yang disukai konsumen pada umumnya. Pada rasa, semakin banyak tepung kulit buah naga merah akan menimbulkan rasa sepat saat dikunyah yang mengurangi kesukaan konsumen. Rasa sepat yang dihasilkan diduga berasal dari senyawa polifenol berupa tanin yang terkandung dalam kulit buah naga merah yang berikatan dengan glikoprotein sehingga menimbulkan rasa sepat. Sejalan dengan Jalaluddin et al., (2015) bahwa tanin merupakan senyawa aromatik polifenol yang terkandung dalam pangan akan menimbulkan aftertaste sedikit pahit. Cookies oats penggunaan $20 \%$ tepung kulit buah naga merah paling disukai oleh panelis yang berpartisipasi karena panelis menyukai keseluruhan dari segi warna merah yang pekat, aroma tidak langu, rasa tidak sepat dan tekstur yang renyah tidak terlalu keras. Didukung Kaltari et al., (2016) menyatakan bahwa cookies yang disukai masyarakat Indonesia cenderung memiliki tekstur yang renyah tidak terlalu keras, rasa manis, aroma khas adonan cookies yang dipanggang dan warna yang menarik untuk dikonsumsi. Walaupun pada cookies oats penggunaan $20 \%$ konsentrasi tepung memiliki tekstur yang tidak berbeda nyata dibandingkan dengan cookies oats perlakuan kontrol, cookies oats perlakuan kontrol memiliki 
skor tekstur yang lebih disukai. Namun secara warna dan rasa memiliki keunggulan tersendiri secara keseluruhan.

\section{SIMPULAN}

Berdasarkan riset yang terlaksanakan disimpulkan bahwa perbedaan persentase konsentrasi tepung kulit buah naga merah berpengaruh pada sifat fisikokimia dan hedonik cookies oats. Penggunaan tepung kulit buah naga merah sebesar $20 \%$ merupakan formulasi terbaik yang ditinjau dari segi aktivitas antioksidan meningkat, tingkat kerenyahan baik, $\mathrm{a}_{\mathrm{w}}$ yang cukup kecil, tingkat warna merah dan kecerahan yang paling tinggi, serta secara keseluruhan perlakuan $\mathrm{T}_{1}$ paling disukai oleh panelis.

\section{SARAN}

Saran dari riset ini berupa tepung kulit buah naga merah perlu diimbangi dengan penambahan komposisi bahan tepung lainnya menjadi tepung komposit untuk menunjang kekurangan yang ada, terutama dari segi tekstur.

\section{DAFTAR PUSTAKA}

Alvionita, J., Darwis, D., dan Efdi, M. (2016). Ekstraksi dan identifikasi senyawa antosianin dari jantung pisang raja (Musa $x$ paradisica L.) serta antiokisdannya. Jurnal Riset Kimia. 9:2, 21.

Budilaksono, W., Wahdaningsih, S., dan Fahrurroji, A. (2014). Uji aktivitas antioksidan fraksi n-heksana kulit buah naga merah (Hylocereus lemairei Britton dan Rose) menggunakan metode DPPH (1,1-Difenil-2-Pikrilhidrazi). Jurnal Mahasiswa Farmasi Fakultas Kedokteran Untan. 1:1, 1-11.

Cahyani, D. A. (2019). Organoleptik cookies dengan substitusi tepung mokaf dan tepung biji durian. Jurnal Ilmiah Media Agrosains. 5:1, 69-76.

Dewi, S., Yayuk, C., dan Maya, A. (2015). Pengaruh substitusi terigu dengan tepung kacang merah pregelatinisasi terhadap sifat fisikokimia dan organoleptik cookies. Jurnal Teknologi Pangan Dan Gizi. 14:2, 67-71.

Girard, A. L., and Awika, J. M. (2020). Effects of edible plant polyphenols on gluten protein functionality and potential applications of polyphenol-gluten interactions. Journal Food Science and Food Safety. 19:4, 2164-2199.

Ingrath, W., Nugroho, W. A., dan Yulianingsih, R. (2015). Ekstraksi pigmen antosianin dari kulit buah naga merah (Hylocereus costaricensis) sebagai pewarna alami makanan dengan menggunakan microwave (kajian waktu pemanasan dengan microwave dan penambahan rasio pelarut aquades dan asam sitrat). Jurnal Bioproses Komoditas Tropis. 3:3,1-8.

Iswara, J. A., Julianti, E. dan Nurminah, M. (2019). Karakteristik tekstur roti manis dari tepung, pati, serat dan pigmen antosianin ubi jalar ungu. Jurnal Pangan Dan Agroindustri. $7: 4,12-21$.

Jalaluddin, J., Ishak, I., dan Rosmayuni, R. (2015). Efektifitas inhibitor ekstrak tanin kulit kayu akasia (Acacia Mangium) terhadap laju korosi baja lunak (ST. 37) dalam media asam klorida. Jurnal Teknologi Kimia Unimal. 4:1, 89-99.

Jalgaonkar, K., Mahawar, M. K., Bibwe, B., and Kannaujia, P. (2020). Postharvest profile, processing and waste utilization of dragon fruit (Hylocereus Spp.). International Journal Food Reviews. 7:2,1-27.

Kaltari, B. I., Setyowati, dan Dewi, D. P. (2016). Pengaruh variasi pencampuran tepung talas bogor (Colocasia esculenta L. Schott) dan kacang merah (Phaseolus Vulganis L.) terhadap sifat fisik, tingkat kesukaan, kadar protein dan kadar serat pada cookies talas rendah protein. Jurnal Nutrisia. 18:1, 51-57.

Mamuaja, C. F., Suryanto, E., dan Kaemba, A. (2017). Karakteristik fisiko-kimia dan aktivitas 
antioksidan beras analog dari sagu baruk (Arenga microcarpha) dan ubi jalar ungu (Ipomea batatas L. Poiret). Jurnal Ilmu Dan Teknologi Pangan. 5:1,1-8.

Manihuruk, F. M., Suryati, T., and Arief, I. I. (2017). Effectiveness of the red dragon fruit (Hylocereus polyrhizus) peel extract as the colorant, antioxidant, and antimicrobial on beef sausage. Journal Media Peternakan. 40:1, 47-54.

Nurliyana, R., Syed Z. I., Mustapha S. K., Aisyah, M. R. and Kamarul R. K. (2010). Antioxidant study of pulps and peels of dragon fruits: A comparative study. International Journal Food Research. 17:2, 367-375.

Rahmawati, W. A., dan Nisa, F. C. (2015). Fortifikasi kalsium cangkang telur pada pembuatan cookies. Jurnal Pangan Dan Agroindustri. 3:3, 1050-1060.

Rochmawati, N. (2019). Pemanfaatan kulit buah naga merah (Hylocereus polyrhizus) sebagai tepung untuk pembuatan cookies. Jurnal Pangan Dan Agroindustri. 7:3, 19-24.

Sánchez-Muniz, F. J. (2012). Dietary fibre and cardiovascular health. Journal Nutricion Hospitalaria. 27:1, 31-45.

Sari, R., Fadilah, R., dan Sukainah, A. (2020). Pengaruh substitusi tepung buah mangrove jenis lindur (Bruguiera gymnorrhiza) terhadap kualitas mie basah. Jurnal Pendidikan Teknologi Pertanian. 6:1, 65-78.

Sarifudin, A., Ekafitri, R., Surahman, D. N., dan Putri, S. K. D. F. A. (2015). Pengaruh penambahan telur pada kandungan proksimat, karakteristik aktivitas air bebas $\left(a_{w}\right)$ dan tekstural snackbar berbasis pisang (Musa paradisiaca). Jurnal Agritech. 35:1, 1-8.

Subandoro, R. H., Basito, dan Windi, A. (2013). P Pemanfaatan tepung millet kuning dan tepung ubi jalar kuning sebagai subtitusi tepung terigu dalam pembuatan cookies terhadap karakteristik organoleptik dan fisikokimia. Jurnal Teknosains Pangan. 2:4, 68-74.

Ulfah, T., Pratama, Y., dan Bintoro, V. P. (2018). Pengaruh proporsi kemangi terhadap aktivitas air $\left(\mathrm{a}_{\mathrm{w}}\right)$ dan kadar air kerupuk kemangi mentah. Jurnal Teknologi Pangan. 2:1, 56-58.

Venturini, L. H., Moreira, T. F. M., da Silva, T. B. V., de Almeida, M. M. C., Francisco, C. R. L., de Oliveira, A., de Campos, S. S., Bilck, A. P., de Souza Leone, R., Tanamati, A. A. C., Gonçalves, O. H., and Leimann F. V. (2019). Partial Substitution of Margarine by Microencapsulated Chia Seeds Oil in the Formulation of Cookies. Journal Food and Bioprocess Technology. 12:1, 77-87.

Vistia, B. F., dan Putri, W. D. R. (2014). Pengaruh penambahan bubuk mawar merah (Rosa damascene Mill.) dengan jenis bahan pengisi berbeda pada cookies. Jurnal Pangan Dan Agroindustri. 2:1, 39-46.

Winarti, S., Sarofa U., dan Wulandari, V. V. (2020). Karakteristik fruit leather dari buah bidara (ziziphus mauritiana) dan kulit buah naga merah serta rumput laut sebagai bahan pengikat. Jurnal Agroindustrial Technology. 14:1, 99-111.

Wulandari, F., Setiani, B. E., dan Susanti, S. (2016). Analisis kandungan gizi, nilai energi, dan uji organoleptik cookies tepung beras dengan substitusi tepung sukun. Jurnal Aplikasi Teknologi Pangan. 5:3, 107-112.

Zhang, Z., Fan, X., Yang, X., Li, C., Gilbert, R. G., and Li, E. (2020). Effects of amylose and amylopectin fine structure on sugar-snap cookie dough rheology and cookie quality. International Journal Carbohydrate Polymers. 241:11, 63-71. 